www.jmscr.igmpublication.org

Impact Factor (SJIF): 6.379

Index Copernicus Value: 71.58

ISSN (e)-2347-176x ISSN (p) 2455-0450

crossref DOI: _https://dx.doi.org/10.18535/jmscr/v6i4.139

Journal Of Medical Science And Clinical Research

\title{
Bacteriological Profile of Semen Specimens in Infertile Males
}

\author{
Authors
}

\section{Riddhi Hathiwala ${ }^{1}$, Archana Bhimrao Wankhade ${ }^{2}$, Poornima Dhandale ${ }^{3}$, Siddhi Hathiwala ${ }^{4}$}

${ }^{1,3}$ Assistant Professor, Dept. of Microbiology, Chandulal Chandrakar Memorial Medical College, Durg, Chattisgarh

${ }^{2}$ Associate Professor, Dept. of Microbiology, Chandulal Chandrakar Memorial Medical College, Durg, Chattisgarh

${ }^{4}$ Assistant Professor, Dept. of Public Health Dentistry, New Horizon Dental College and Research Institute

Bilaspur, Chattisgarh, India

Corresponding Author

\section{Riddhi Hathiwala}

Assistant Professor, Dept. of Microbiology, Chandulal Chandrakar Memorial Medical College, Durg, Chattisgarh, India

Email: riddhihathiwala@gmail.com, Cont. No.: 9833049504

\section{Abstract}

Introduction: Infertility constitutes a grave emotional and social problem in India. Male urogenital tract infection is one of the most important causes of male infertility and has been associated with 8-35\% of male infertility cases. Presence of bacteria in semen samples may compromise the sperm quality.

Aim: To study the microbiological profile of the semen specimens collected from adult married males visiting the infertility centres.

Material and Methods: In this study, a total of 115 semen samples were collected, after informed written consent, from married males who visited the infertility centres. Semen analysis was carried out according to WHO guidelines (2010). The specimens were processed using standard microbiological procedures for isolating and identifying the organism, followed by antibiotic susceptibility testing. The results were recorded and analysed.

Results: A total of 115 semen specimens were cultured, of which $48(41.7 \%)$ showed significant bacterial growth. About $67 \%$ isolates were gram positive cocci and $33.3 \%$ isolates were gram negative. The commonest isolates were Enterococcus species (25\%) and Escherichia coli (23\%). Most of the Gram positive cocci were sensitive to Linezolid, Vancomycin, Teicoplanin and Nitrofurantoin. Most of the Gram negative bacilli were sensitive to Amikacin, Piperacillin-Tazobactum, Gentamicin, Nitrofurantoin and Imipenem. The sensitivity to Co-trimoxazole, Penicillin and Ciprofloxacin was quite low. Oligozoospermia was seen in 61 (53\%) of the specimens, out of which 30 showed significant bacterial growth.

Conclusion: Testing for the bacteriological profile of semen of infertile males should be done routinely as bacteria may affect the quality of semen.

Keywords: Semen, Infertility, Bacterial infections, Antibiotic sensitivity, Oligozoospermia.

\section{Introduction}

Infertility constitutes a grave emotional and social problem in societies where great importance is attached to having children. Infertility is defined as inability to achieve conception in a period of 1 year in a couple, despite regular and adequate unprotected sexual intercourse ${ }^{[1]}$. It is widely accepted that male factor alone accounts for 
infertility in about $40 \%$ couples facing infertility; female factor alone in $40 \%$ of the couples; and in other $20 \%$, there is a combined male and female factor. In India, the prevalence of primary infertility is estimated to be about $10-20 \%{ }^{[2]}$.

Semen is a mixture of spermatozoa and fluids derived from the epididymis and the bulbourethral, urethral and prostate glands ${ }^{[3]}$. The glands and organs that contribute to the semen are considered sterile. The sterility of the internal urethra is maintained by the normal flow of urine; however, the distal urethra is not considered a sterile area. Therefore, the culturing of semen samples usually yields growth of organisms, many of which are considered to be normal flora of the genitourinary tract ${ }^{[4]}$. Semen contamination arises from the urinary tract of patients or can be sexually transmitted from the partner. The presence of other pathogens in concentrations $\geq 10^{3}$ bacteria/ $\mathrm{ml}$ of ejaculate (bacteriospermia) is clinically regarded as a sign of an active infection ${ }^{[5,6]}$.

Male urogenital tract infection is one of the most important causes of male infertility worldwide. Genital tract infection and inflammation have been associated to $8-35 \%$ of male infertility cases ${ }^{[7-10]}$. Presence of bacteria in semen samples may compromise the sperm quality, by affecting sperm motility, morphology, or causing deterioration of spermatogenesis, obstruction of the seminal tract, autoimmune processes and dysfunction of accessory sex glands $^{[6,8,10]}$. Moreover this may lead to transmission of the infection to the female partner as well as the possible illnesses of the offspring. Hence, there is a need to detect the microbial agents present in semen of males with doubtful fertility and their antibiotic susceptibility pattern to control the infection.

\section{Aim}

To study the microbiological profile of the semen specimens collected from adult married males visiting the infertility centres.

\section{Material and Methods}

This study was conducted in a tertiary care teaching institute, located in Central India during April, 2015 to March, 2016. The procedure and purpose of the study was explained and written informed consent was taken from all the participants. Semen sample of 115 adult married men attending the infertility clinics were collected by masturbation, after 3-5 days of abstinence period. The patients were advised not to consume any antibiotic for about a week before collection of semen sample. They were advised to wash their hands and genital area with soap and water and to urinate before collection of semen sample, to prevent contamination. Samples were collected into sterile universal containers.

All specimen collected were immediately transferred to Microbiology Laboratory after collection. Semen analysis was carried out according to WHO guidelines (2010) after liquefaction for $30 \mathrm{~min}$ at $37{ }^{\circ} \mathrm{C}$, for assessing $\mathrm{pH}$, volume, presence of pus/red blood cells, sperm motility, sperm concentration and abnormal morphology ${ }^{[5]}$. All the specimens were processed using standard microbiological procedures for isolating and identifying the organisms. They were cultured by the semi-quantitative culture technique using a standard calibrated loop on Blood, MacConkey and Chocolate agar. Samples were incubated in a microaerophilic $\left(5 \% \mathrm{CO}_{2}\right)$ and aerobic conditions at $37{ }^{\circ} \mathrm{C}$ overnight ${ }^{[11]}$. Culture for strict anaerobic organisms was not a part of the study and was not performed. Seminoculture was considered positive when the number of colonies was $\geq 10^{3}$ bacteria/ $\mathrm{ml}$ of ejaculate ${ }^{[5,6]}$. Mixed growths were considered as urethral contamination and hence, were not processed further. The identification of bacterial isolates was made using standard microbiological techniques as described in Bergey's Manual of Systemic Bacteriology which comprise of studying the colony characters, staining reactions and biochemical tests ${ }^{[12]}$. Antibiotic susceptibility testing was performed by Kirby Bauer disk diffusion method as per the CLSI (2015) recommendations ${ }^{[13]}$. The antibiotic 
disks used for the susceptibility testing were procured from Hi-Media Laboratories Pvt. Limited. The results were recorded and analysed for descriptive details.

\section{Results}

A total of 115 semen specimens were included in this study. Out of them, $48(41.7 \%)$ showed significant bacterial growth i.e. $\geq 10^{3}$ bacteria $/ \mathrm{ml}$ of semen ejaculate. About 32 (67\%) isolates were Gram positive cocci (GPC) and 16 (33.3\%) isolates were Gram negative bacilli (GNB). The commonest isolates were Enterococcus species (25\%), followed by Escherichia coli (23\%), Coagulase Negative Staphylococcus species, Staphylococcus aureus, Proteus species and Pseudomonas aeruginosa. (Table 1)

Among the GPC isolated, all were sensitive to Linezolid, Vancomycin and Teicoplanin, and most of them were sensitive to Nitrofurantoin $(87.5 \%)$. (Table 2) Among the GNB isolated, most were sensitive to Amikacin (87.5\%) and PiperacillinTazobactum (87.5\%), and lesser sensitivity was seen for Gentamicin, Nitrofurantoin and Imipenem (70\%). (Table 3) The sensitivity to Cotrimoxazole (44\%), Penicillin (40\%) and Ciprofloxacin $(36.2 \%)$ was quite low.

Of all the 115 semen specimens studied, 61 (53\%) were oligozoospermic (20-60 million $/ \mathrm{ml}), 42$ (36.5\%) were normozoospermic ( $>60$ million/ml), and $12(10.4 \%)$ patients had azoospermia $(<20$ million/ml). Of the 48 significant bacterial growth recovered, $30(62.5 \%)$ were recovered from the oligozoospermic patients, $14(21.16 \%)$ from the normozoospermic and 4 (8.3\%) from azoospermic cases. (Table 4)

The most common age group among the participants was $25-30$ years $(42.6 \%)$, followed by $31-35$ (37.5\%). The maximum numbers of culture positive cases (48\%) were found in patients 25-30 year age group. (Table 5)

Table 1 Distribution of organisms in Semen according to their species

\begin{tabular}{|l|c|c|}
\hline Pathogens & Number $(\mathbf{N}=\mathbf{1 1 5})$ & Percentages $(\%)$ \\
\hline Gram Positive Cocci & $\mathbf{3 2}$ & $\mathbf{2 7 . 8 2}$ \\
\hline Enterococcus species & 12 & 10.43 \\
\hline Staphylococcus aureus & 06 & 5.21 \\
\hline CoNS & 13 & 11.3 \\
\hline Streptococcus species & 01 & 0.87 \\
\hline Gram Negative Bacilli & $\mathbf{1 6}$ & $\mathbf{1 3 . 9}$ \\
\hline Escherichia coli & 11 & 9.56 \\
\hline Proteus species & 03 & 2.6 \\
\hline Pseudomonas aeruginosa & 02 & 1.73 \\
\hline Contaminants & $\mathbf{1 0}$ & $\mathbf{8 . 7}$ \\
\hline No Growth & $\mathbf{5 7}$ & $\mathbf{4 9 . 5 6}$ \\
\hline
\end{tabular}

Table 2 Antibiotic Sensitivity pattern of Gram Positive organisms in Semen

\begin{tabular}{|c|c|c|c|c|c|c|c|c|c|c|}
\hline \multirow{2}{*}{$\begin{array}{l}\text { Organisms } \\
\text { Antibiotics }\end{array}$} & \multicolumn{2}{|c|}{$\begin{array}{l}\text { Staphylococcus } \\
\text { aureus }(\mathbf{N}=6)\end{array}$} & \multicolumn{2}{|c|}{$\begin{array}{c}\text { Enterococcus } \\
\text { species }(N=12)\end{array}$} & \multicolumn{2}{|c|}{$\operatorname{CoNS}(N=13)$} & \multicolumn{2}{|c|}{$\begin{array}{l}\text { Streptococcus } \\
\text { species }(\mathbf{N}=\mathbf{1})\end{array}$} & \multicolumn{2}{|c|}{$\begin{array}{l}\text { Gram Positive } \\
\text { Cocci }(\mathbf{N}=32)\end{array}$} \\
\hline & S(\%) & $\mathbf{R}(\%)$ & S(\%) & $\mathbf{R}(\%)$ & S(\%) & R (\%) & $\mathbf{S ( \% )}$ & R (\%) & $\mathbf{S}(\%)$ & $\mathbf{R}(\%)$ \\
\hline Cefoxitin & 33.3 & 66.6 & - & - & 30.76 & 69.23 & 100 & 00 & 35 & 65 \\
\hline Linezolid & 100 & 00 & 100 & 00 & 100 & 00 & 100 & 00 & 100 & 00 \\
\hline Vancomycin & 100 & 00 & 100 & 00 & 100 & 00 & 100 & 00 & 100 & 00 \\
\hline Teicoplanin & 100 & 00 & 100 & 00 & 100 & 00 & 100 & 00 & 100 & 00 \\
\hline Penicillin & 33.3 & 66.6 & 75 & 25 & 7.69 & 92.3 & 100 & 00 & 40.6 & 59.4 \\
\hline Nitrofurantoin & 83.33 & 16.66 & 91.66 & 8.33 & 92.3 & 7.69 & 100 & 00 & 90.6 & 9.4 \\
\hline Ciprofloxacin & 33.3 & 66.6 & 25 & 75 & 30.76 & 69.23 & - & - & 28.1 & 71.9 \\
\hline Co-trimoxazole & 50 & 50 & - & - & 38.46 & 61.53 & 100 & 00 & 45 & 55 \\
\hline Gentamicin & 50 & 50 & 66.66 & 33.33 & 61.53 & 38.46 & - & - & 61.2 & 38.8 \\
\hline
\end{tabular}

* $\mathrm{S}=$ Sensitive, $\mathrm{R}=$ Resistant 
Table 3 Antibiotic Sensitivity pattern of Gram Negative organisms in Semen

\begin{tabular}{|l|c|c|c|c|c|c|c|c|}
\hline Organisms & \multicolumn{2}{|c|}{$\begin{array}{c}\text { Escherichia coli (N } \\
\mathbf{1 1})\end{array}$} & \multicolumn{2}{c|}{$\begin{array}{c}\text { Proteus species (N } \\
\mathbf{3})\end{array}$} & \multicolumn{2}{c|}{$\begin{array}{c}\text { Pseudomonas } \\
\text { aeruginosa (N = 2) }\end{array}$} & \multicolumn{2}{c|}{$\begin{array}{c}\text { Gram Negative } \\
\text { Bacilli (N = 32) }\end{array}$} \\
\hline Antibiotics & $\mathbf{S ( \% )}$ & $\mathbf{R}(\%)$ & $\mathbf{S ~ ( \% )}$ & $\mathbf{R}(\boldsymbol{\%})$ & $\mathbf{S}(\%)$ & $\mathbf{R}(\%)$ & $\mathbf{S}(\%)$ & $\mathbf{R}(\%)$ \\
\hline Amikacin & 90.9 & 9.09 & 100 & 00 & 50 & 50 & 87.5 & 12.5 \\
\hline Gentamicin & 63.63 & 36.36 & 66.66 & 33.33 & 100 & 00 & 68.75 & 31.25 \\
\hline Imipenem & 63.63 & 36.36 & 66.66 & 33.33 & 100 & 00 & 68.75 & 31.25 \\
\hline $\begin{array}{l}\text { Piperacillin- } \\
\text { Tazobactum }\end{array}$ & 72.72 & 27.27 & 100 & 00 & 100 & 00 & 81.25 & 18.75 \\
\hline Nitrofurantoin & 72.72 & 27.27 & - & - & 50 & 50 & 70 & 30 \\
\hline Ciprofloxacin & 36.36 & 63.63 & 100 & 00 & 50 & 50 & 50 & 50 \\
\hline Co-trimoxazole & 45.45 & 54.54 & 33.33 & 66.66 & - & - & 42.85 & 57.15 \\
\hline
\end{tabular}

$* \mathrm{~S}=$ Sensitive, $\mathrm{R}=$ Resistant

Table 4 Distribution of the Semen isolates according to sperm count

\begin{tabular}{|l|c|c|c|}
\hline Organisms & Oligozoospermia & Normozoospermia & Azoospermia \\
\hline Enterococcus species & 8 & 3 & 1 \\
\hline Escherichia coli & 6 & 4 & 1 \\
\hline Staphylococcus aureus & 5 & 1 & 0 \\
\hline CoNS & 7 & 5 & 1 \\
\hline Proteus species & 1 & 1 & 1 \\
\hline Pseudomonas aeruginosa & 2 & 0 & 0 \\
\hline Streptococcus species & 1 & 0 & 0 \\
\hline Total & 30 & 14 & 4 \\
\hline
\end{tabular}

Table 5 Age-wise distribution of the study participants

\begin{tabular}{|l|c|c|}
\hline Age groups (Years) & $\begin{array}{c}\text { No. of participants (\%) } \\
(\mathbf{N}=\mathbf{1 1 5})\end{array}$ & $\begin{array}{c}\text { Culture Positive (\%) } \\
(\mathbf{N}=\mathbf{4 8})\end{array}$ \\
\hline $\mathbf{2 5 - 3 0}$ & 42.6 & 47.9 \\
\hline $\mathbf{3 1 - 3 5}$ & 37.4 & 29.16 \\
\hline $\mathbf{3 6 - 4 0}$ & 8.69 & 8.33 \\
\hline $\mathbf{4 1 - 4 5}$ & 7.82 & 10.4 \\
\hline$>\mathbf{4 6}$ & 3.47 & 4.16 \\
\hline
\end{tabular}

\section{Discussion}

Infertility is a globally increasing problem with increasing use of Assisted Reproductive Techniques. Since male genital tract infections are often linked to poor sperm motility and function, proper bacteriological testing of the semen including antibiotic resistance should also be included in andrological diagnostic workup for infertility testing. By doing so, a significant number of patients can be treated, as these infections are potentially treatable with an appropriate antibiotic therapy. This in turn will help in preventing the transmission of the infection to the female partner as well as the possible illnesses of the offspring due to infection [14]

The source of microorganisms in semen specimen is doubtful as the glands and organs that contribute to the semen are considered sterile, but normal microflora exists in urethra and on genital skin ${ }^{[15,16]}$. In this study, all attempts were made to minimise the contamination of the specimens from the skin and urethra by washing the hands and genital organ with soap and water and urinating before collection of semen sample. These measures might be a reason that culture was found to be sterile in 57 (49.5\%) of specimens, and contaminant growth was found only in $10(8.7 \%)$ of the specimens in this study.

In our study, the significant bacterial growth was seen in $41.6 \%$ of semen specimens. Literature shows a wide variation of isolation; Moretti, et al. reported $33.2 \%$ isolation, Enwuru, et al. reported $70.4 \%$ isolation, Bhatt, et al. reported $17.8 \%$ isolation, while Mogra, et al. found $42.9 \%$ significant bacterial growth ${ }^{[17-20]}$. 
In this study, about 32 (67\%) isolates were GPC and $16(33.3 \%)$ isolates were GNB. Moretti, et al. isolated $64 \%$ and $36 \%$, respectively, which was similar to our study results. Different results were found in other studies, where Enwuru, et al. isolated $49.4 \%$ and $21 \%$, respectively; Bhatt, et al. isolated $37 \%$ and $63 \%$ respectively and Isaiah, et al. isolated about $48 \%$ of GPC and $52 \%$ of GNB [17-19, 21]

E. coli (10\%) and Enterococci (10.5\%) were detected as the most common isolates from the semen specimen in this study. They are the common bacteria of the intestinal tract. Hillier, et al. detected both the types of bacteria in $13 \%$ of their patients. Moretti, et al. isolated in $20.3 \%$ and $32 \%$, respectively; Mogra, et al. isolated $17.1 \%$ and $31.4 \%$, respectively; Enwuru, et al. reported $10.5 \%$ of E. coli and $29.6 \%$ of Staphylococcus species; while in study done by Bhatt, et al. the commonest isolates were E. coli $(41.9 \%)$ and S. aureus $(17.7 \%)^{[17-20,22]}$.

Escherichia coli was the most frequently isolated microorganism in male patients with genital tract infections or semen contamination. The deleterious effect of E. coli on male fertility and specifically sperm quality is due to its effects on sperm motility [23] and the impairment of acrosome reaction ${ }^{[16]}$. A report by Moretti, et al. [17] suggested that bacterial flagella and pili (contact accessory structures) of E. coli could be an important determinant of pathogenicity. The possible mechanism of sperm damage, in addition to the adhesion of pili, consists of the production of toxins and metabolic products that induce apoptosis, resulting in a breakdown in the mitochondrial membrane potential ${ }^{[24]}$.

In this study, about $32(67 \%)$ isolates were GPC. Mehta, et al. reported that aerobic cocci are present in about $50 \%$ of semen samples of male partners in infertile couples. Enterococcus faecalis was isolated from $53 \%$ of patients. The influence of gram-positive uropathogenic bacteria on sperm morphology and function has not been completely investigated until now. Genito-urinary infections caused by E. faecalis are associated with compromised semen quality in terms of sperm concentration and morphology ${ }^{[25]}$. In an in vitro study, the researchers described a negative influence on membrane integrity of human sperm head, neck and mid-piece, probably mediated by hemolysin, a well-known virulence factor of enterococci $^{[26]}$.

In this study, most of the GPC were found to be sensitive to Linezolid, Vancomycin, Teicoplanin and Nitrofurantoin and most of the GNB were found to be sensitive to Amikacin, PiperacillinTazobactum, Gentamicin, Imipenem and Nitrofurantoin. The sensitivity to Co-trimoxazole, Penicillin and Ciprofloxacin was quite low $(\approx 40 \%)$. Similar results were reported by other authors ${ }^{[19,20,27]}$. The decreasing sensitivity of the bacterial isolates against Co-trimoxazole, Penicillin, Ciprofloxacin and Gentamicin reflects upon the practice of too frequent, inadequate and indiscriminate use of these antibiotics for treatment ${ }^{[28]}$.

The results of our study showed that $61(53 \%)$ specimens were oligozoospermic, 42 (36.5\%) normozoospermic, and $12(10.4 \%)$ patients had azoospermia. This was similar to other studies done for semen analysis. Enwuru, et al. reported $52.5 \%, 33.3 \%$ and $14.2 \%$, respectively. They had the opinion that the bacterial contamination of semen affects sperm quality in the form of oligozoospermia and hence cause infertility. They reported that semen contamination by GPC was associated with overall lower mean sperm concentration ${ }^{[18]}$. This was in accordance with the report of in vitro study conducted by Qiang, et al. [26]. The relatively increased count of oligozoospermic and azoospermia specimens $(63.4 \%)$ seen in this study, can be attributed to the increased ratio of GPC as compared to GNB (67\%: 33.3\%).

In this study, the maximum number of the participants $(42.6 \%)$ and culture positive specimens $(48 \%)$ were from the $25-30$ years age group. The study conducted by Bhatt, et al. reported maximum culture positivity in specimens from 31-40 years age group (46.7\%), while 21-30 
years age group had only $29 \%$ of culture positivity [19]. The differences could be due to demographic factors.

Many studies have examined the impact of genital tract infections and bacterial semen contamination in male fertility; however, the detrimental effect of bacteria on the sperm quality is still controversial $[29,30]$. There are studies which suggest that presence of bacteria in semen samples may compromise the sperm quality, by affecting sperm motility, morphology, spermatogenesis, obstruction of the seminal tract, and autoimmune processes ${ }^{[6,8,10]}$. There are other studies which report that the bacteria isolated from the genitourinary tracts of men have no effect on semen quality in normozoospermic males; however, in infertile men, it is possible that bacteria further deteriorate the whole quality of the seminal plasma ${ }^{[17,31]}$. Several investigations which assessed in vitro fertilization indicated that oocyte fertilization was reduced in the presence of pathogenic organisms in semen ${ }^{[32]}$ and concluded that semen bacterial contamination reduces semen quality and interferes with fertilization. Enwuru, et al. had the opinion that bacterial contamination of semen affects sperm quality and hence causes infertility. They reported that Gram negative organisms' presence in semen may affect the quality in terms of motility while Gram positive bacteria resulted into overall lower mean sperm concentration $^{[18]}$

\section{Conclusion}

This study done on semen specimens of males with complaint of infertile showed that about $42 \%$ had bacterial pathogens. Enterococcus species were found to be the commonest organism followed by E.coli. Nitrofurantoin was active against most of the organisms isolated and can be used as drug of choice for genito-urinary tract infections; but most of the organisms were resistant to Co-trimoxazole, Penicillin and Ciprofloxacin. Most of the semen specimens collected from 25-30 years age group were found to be culture positive. It is so, highly recommended that the semen of infertile males should be tested routinely for their bacteriological profile as bacteria may affect the quality of semen.

\section{Acknowledgement}

Authors sincerely thank all the faculty and staff of Department of Microbiology, Chandulal Chandrakar Memorial Medical College, Kachandur, Durg, for their constant support. Authors also thank sincerely the patients who contributed in the completion of this study. Authors also acknowledge the immense help received from the scholars whose articles are cited and included in references of this manuscript.

Conflict of Interests: No conflict of interests declared.

\section{References}

1. Zegers-Hochschild F, Adamson GD, de Mouzon J, Ishihara O, Mansour R, Nygren $\mathrm{K}$, et al. ICMART and WHO international committee for monitoring assisted reproductive technology (ICMART) and the World Health Organization (WHO) revised glossary of ART terminology, 2009. Fertil Steril 2009; 92: 1520-4.

2. Sigman M, Lipshultz LI, Howards SS. Evaluation of the subfertile male. In: Lipshultz LI, Howards SS (eds), Infertility in the Male. $4^{\text {th }}$ ed. St. Louis, Missouri: Mosby-Year Book; 1997: 173.

3. Mawhinney M. Male accessory sex organs and androgen action. In: Lipshultz L, Howards SS (eds), Infertility in the Male. Churchill Livingstone, New York, 1983 pp 135-65.

4. Shalika S, Dugan K, Smith RD, Padilla SL. The effect of positive semen bacterial and Ureaplasma cultures on in-vitro fertilization success. Hum Reprod 1996; 11: 2789-92.

5. World Health Organization. WHO Laboratory Manual for the Examination and Processing of Human Semen. $5^{\text {th }}$ ed. 
World Health Organization, Geneva, Switzerland; 2010.

6. Purvis K, Christiansen E. Infection in the male reproductive tract. Impact, diagnosis and treatment in relation to male infertility. Int J Androl 1993; 16: 1-13. doi: 10.1111/j.1365-2605.1993.tb01146

7. Elnhar A. Male genital tract infection: the point of view of the bacteriologist. Gynecol Obstetrique Fertili 2005; 33: 691-7.

8. Bukharin OV, Kuzmin MD, Ivanov IB. The role of the microbial factor in the pathogenesis of male infertility. $\mathrm{Zh}$ Mikrobiol Epidemiol Immunobiol 2000; 2: 106-10.

9. Ibadin OK, Ibeh IN. Bacteriospermia and sperm quality in infertile male patient at University of Benin Teaching Hospital, Benin City, Nigeria. Mala J Microbiol 2008; 4: 65-7.

10. Keck C, Gerber-Schafer C, Clad A, Wihelm C, Breckwoldf M. Seminal tract infections: impact on male fertility and treatment options. Hum Reproduct Update 1998; 4: 891-903.

11. Shaban SF. Male infertility overview: assessment, diagnosis and treatment. In: IVF.com Georgia Reproductive Specialists [online]. Available at: www.ivf.com/shaban.html. Accessed on $25^{\text {th }}$ Jan, 2018.

12. Geoge MD, David RB, Richard WC. Bergey's manual of Systemic Bacteriology $2^{\text {nd }}$ ed. Springer, NY; 2001

13. Clinical Laboratory Standards Institute: Performance standards for antimicrobial disk susceptibility tests, Wayne (PA): CLSI 2015 (M100-S25).

14. Solomon M, Henkel R. Semen culture and the assessment of genitourinary tract infections. Indian J Urol 2017; 33: 188-93

15. Hochreiter WW, Duncan JL, Schaeffer AJ. Evaluation of the bacterial flora of the prostate using 16s RNA gene based polymerase chain reaction. J Urol 2000; 163: 127-30.

16. Diemer T, Ludwig M, Huwe P, Hales DB, Weidner W. Influence of urogenital infection on sperm function. Curr Opin Urol 2000; 10: 39-44.

17. Moretti E, Capitani S, Figura N, Pammolli A, Federico MG, Giannerini V, et al. The presence of bacteria species in semen and sperm quality. J Assist Reprod Genet 2009; 26: 47-56.

18. Enwuru CA, Iwalokun B, Enwuru VN, Ezechi O, Oluwadun A. The effect of presence of facultative bacteria species on semen and sperm quality of men seeking fertility care. Afr J Urol 2016; 22: 213-22.

19. Bhatt CP, Mishra S, Bhatt AD, Lakhey M. Bacterial pathogens in semen culture and their antibiotic susceptibility pattern in vitro. Int J Biomed Res 2015; 6: 909-14.

20. Mogra N, Dhruva A, Kothari LK. Nonspecific seminal infection and male infertility: A bacteriological study. J Post Grad Med 1981; 27: 99-104.

21. Isaiah IN, Nche BT, Nwagu IG, Nnanna II. Current studies on bacterospermia the leading cause of male infertility: a protégé and potential threat towards mans extinction. North Am J Med Sci 2011; 3: 562-564. doi: 10.4297/najms.2011.3559

22. Hillier SL, Rabe LK, Mueller $\mathrm{CH}$, Zarutskie P, Kuzan FB, Stenchever MA. Relationship of bacteriologic characteristics to semen indices in men attending an infertility clinic. Obstet Gynecol 1990; 75: 800-4.

23. Diemer T, Huwe P, Ludwig M, SchroederPrintzen I, Michelmann HW, Schiefer HG, et al. Influence of autogenous leucocytes and Escherichia coli on sperm motility parameters in vitro. Andrologia 2003; 35: 100-5.

24. Schulz M, Sánchez R, Soto L, Risopatrón J, Villegas J. Effect of Escherichia coli and its soluble factors on mitochondrial 
membrane potential, phosphatidylserine translocation, viability, and motility of human spermatozoa. Fertil Steril 2010; 94: 619-23.

25. Mehta RH, Sridhar H, Vijay Kumar BR, Anand Kumar TC. High incidence of oligozoospermia and teratozoospermia in human semen infected with the aerobic bacterium Streptococcus faecalis. Reprod Biomed Online 2002; 5: 17-21.

26. Qiang H, Jiang MS, Lin JY, He WM. Influence of enterococci on human sperm membrane in vitro. Asian J Androl 2007; 9: 77-81. doi: 10.1111/j.17457262.2007.00219.

27. Marin HK. Inadequate anti-microbial treatment and an important determinant of outcome for hospitalized patients. Clin Infect Dis 2000; 31: 5131-8.

28. Wadile RG. Male genitourinary tract infections relationship with infertility: A bacteriological study. Int J Pharm Bio Sci 2013; 4: 913-7.

29. Haidl G. Macrophages in semen are indicative of chronic epididymal infection. Arch Androl 1990; 25: 5-11. doi:10.3109/01485019008987587.

30. Sikka SC. Role of oxidative stress and antioxidant in andrology and assisted reproductive technology. J Androl 2004; 25: 5-19.

31. Sanocka-Maciejewska D, Ciupińska M, Kurpisz M. Bacterial infection and semen quality. J Reprod Immunol 2005; 67: 51-6. doi:10.1016/j.jri.2005.06.003.

32. Almond GW, Poolperm P. Semen contamination and choosing antibiotics. In: Proceedings of the North Carolina healthy hogs seminar. 1996. p. 17-20. Available at: www.ncsu.edu/project/swine_extension/he althyhogs/book1996/book96_5.html. 